\title{
E-shopping: an Analysis of the Technology Acceptance Model
}

\author{
Weng Marc Lim \\ School of Business, Monash University \\ Jalan Lagoon Selatan, Bandar Sunway 46150, Selangor, Malaysia \\ E-mail: lim.weng.marc@monash.edu \\ Ding Hooi Ting \\ School of Business, Monash University \\ Jalan Lagoon Selatan, Bandar Sunway 46150, Selangor, Malaysia \\ E-mail: ting.ding.hooi@monash.edu
}

Received: January 31, 2012

Accepted: February 14, $2012 \quad$ Published: April 1, 2012

doi:10.5539/mas.v6n4p49

URL: http://dx.doi.org/10.5539/mas.v6n4p49

\begin{abstract}
One of the continuing issues in the management of information technologies is the difficulty of identifying significant factors that influences consumers to accept and make use of systems developed and implemented by others. Existing studies have employed the technology acceptance model (TAM) to address this issue and the model has now become one of the most widely used models in information technology. However, an exhaustive review of the literature suggest that findings of TAM relationships are not borne out in all studies - there remains a wide variation of predicted effects in various studies with different types of users and systems. While there are existing studies concentrated on online shopping globally, many conclude with calls for a closer examination of online shopping intentions in specific countries, typically those in developing and less developed countries. Online shopping remains in the early stage of development in Malaysia. Little is known about the acceptance of online shopping and the factors which influence this behaviour. This study attempts to fill in this gap by providing insights on how consumers form their attitudes and online shopping intentions to the existing literature and managerial implications for online shopping retailers and marketers on how best to serve and attract consumers to shop online via the management of online shopping technologies.
\end{abstract}

Keywords: E-shopping, Technology acceptance model, Perceived ease of use, Perceived usefulness, Attitude towards online shopping, Intention to shop online

\section{Introduction}

The process of growing the Internet in the recent years has been genuinely perceived as an extraordinary event (Krishna \& Guru, 2010). Research indicates that the development of the commercial trade that is carried out through the Internet has surprisingly changed the retail vista in the world economy since 1990 (Chen \& Chang, 2003). This is supported by Delafrooz et al. (2010) as the usage of the Internet in the contemporary era is no longer limited as a networking media, but it is also being used as a means of transaction for consumers in the global market. Nielson (2008) has published the overall online shopping trends in the late 2000. Notably, over 875 million consumers have shopped online. The number of online shoppers has also increased up to $40 \%$ in the last two years. Among Internet users with Internet access shopping, the highest percentage for online shopping is found in South Korea (99\%), UK (97\%), Germany (97\%), Japan (97\%), and US (94\%). Furthermore, more recent statistics by Forrester Research Inc predicts that online retail revenue will grow from $\$ 191.7$ billion in 2011 to $\$ 248.7$ billion in 2014, representing an 8 percent compound annual growth rate (Schonfeld, 2010). As a result, by expansion of the online shopping trend due to its convenience, numerous companies and enterprises are finding it as an opportunity to join in order to stay competitive (Kau, et al., 2003) and thus have spent a considerable amount of resources in a quest to retain and expand customer base. However, Forouhandeh et al. (2011) argued that the dramatic development of commerce through the Internet has also brought forth many new challenges. 
According to Pastore (2000), despite the significant increase of online shopping in the past, fewer consumers than anticipated actually purchase electronically. In reality, many consumers increasingly use the medium to obtain information but not for purchasing products. Furthermore, there seem to be inadequate information on how and why certain groups of consumers engage in online shopping whereas others accept online shopping reluctantly (Kamarulzaman, 2008). Indeed, one of the continuing issues in the management of information technologies is that of identifying factors that cause people to accept and make use of systems developed and implemented by others (King \& He, 2006). This is supported by Grabner-Krauter and Kaluscha (2003) as many consumers are still reluctant to shop online due to improper implementations of online technologies and infrastructures, which has often caused much confusion and difficulty in consumer online shopping activities, and therefore has been attributed as factors that mostly lead to the lost of online retail sales.

Over the decades, various theories and approaches have been put forth to address this problem. In 1989, Davis (1989) proposed the technology acceptance model (TAM) to explain the potential user's behavioural intention to use a technological innovation. TAM is based on the theory of reasoned action (TRA), a psychological theory that seeks to explain behaviour (Fishbein \& Ajzen, 1975), and involves two primary predictors - perceived ease of use (PEOU) and perceived usefulness (PU) and the dependent variable behavioural intention (BI), which TRA assumed to be closely linked to actual behaviour. Indeed, TAM has now become one of the widely used models in information technology, in part because of its understandability and simplicity (King \& He, 2006). However, Legris et al. (2003) argued that it is imperfect as all TAM relationships are not borne out in all studies - there remains a wide variation in the predicted effects in various studies with different types of users and systems.

While there are existing studies concentrated on online shopping around the world, many of these studies conclude that there is still a need for closer examination of the online shopping intention in specific countries, very much due to the fact of cultural differences and the prior imperfection of technology acceptance relationships of varying consumer markets (Bobbit \& Dabholkar, 2001; Goldsmith, 2002; Salisbury, et al., 2001). Considering that online shopping is still at the early stage of development in Malaysia, little is known about consumers' behaviour in adopting this new shopping channel and the factors which influence this behaviour (Haque, et al., 2006). This study attempts to fill in this gap by examining how consumers form their attitudes and make online shopping intentions. This study employs TAM as the underlying theoretical grounding for the research framework as it provides a valid basis for explaining and predicting consumers' intention towards online shopping behaviour (Bobbit \& Dabholkar, 2001; Goldsmith, 2002; Grabner-Krauter \& Kaluscha, 2003; Haque, et al., 2006; King \& He, 2006). The knowledge this study generates will contribute in two ways: in terms of theory, this study provides an empirical understanding on the technology acceptance of Malaysian consumers towards online shopping; and in terms of practice, this study presents strategic implications and directions for the development of online shopping in Malaysia.

\section{Literature Review}

\subsection{Technology Acceptance Model (TAM)}

Based on established pertinent theoretical foundations and literature, a research model has been employed to investigate the technology acceptance factors that influence the adoption of online shopping within the context of Malaysian consumers. The TAM (Davis, 1989), with its basis in the TRA (Ajzen, 1991; Fishbein \& Ajzen, 1975) has emerged as a powerful model in investigating the acceptance and use of information technology; its relationship to TRA has been discussed extensively in the literature (Davis, 1989; Keil, et al., 1995; Mitchell \& Greatorex, 1993; Roger, 1995) and need not be elaborated here. The choice for using TAM as a research model to explain consumers' online shopping adoption is attributed to its consistent capability to explain a substantial portion of variances between behavioural intention and actual behaviours derived mainly from research into the purchase of technology related products (Bobbit \& Dabholkar, 2001; Goldsmith, 2002; Grabner-Krauter \& Kaluscha, 2003; Hanque, et al., 2006; King \& He, 2006).

The TAM postulates that the perceptions or beliefs about the innovation are instrumental in the development of attitudes that will eventually result in system utilization behaviour (Davis, 1989). It also posits that the actual system use is determined by each user's behavioural intention to use, which is in turn influenced by each user's attitudes towards use. Finally, the attitude is directly affected by the usefulness and ease of use of the system. Although this model was originally conceived to model the adoption of information systems in the workplace (Davis, 1989), scholars in the area of consumer behaviour have identified two specific dimensions which are relevant to online shopping: perceived ease of use and perceived usefulness (Gefen, et al., 2003; Huang, 2008).

\subsection{Perceived Ease of Use (PEOU)}

According to TAM, PEOU is a major determinant that affects acceptance of a particular technology (Davis, et al., 
1989). PEOU is defined as the concentration of physical and mental efforts that a user expects to receive when considering the use of technology i.e. the degree to which a particular technological system would be free from effort (Davis, 1989). According to Buton-Jones and Hubona (2005), the ease of learning and becoming skilful at using pervasive technologies, including technologies and interfaces on online shopping sites, were concluded as valid determinants as to what makes a technology easy to use. The work of Selamat et al. (2009) further added that a technology which is perceived to be easier to use than another is more likely to be accepted by users whereas the more complex a technology is perceived to be, the slower will be its rate of adoption. This is supported by Teo (2001) as the study concluded that a system which is easy to use often requires less effort on the part of users and thereby increases the likelihood of adoption and usage of a particular technology. Other scholars have also found that the perceived ease of use had a positive influence on consumers' attitude in using the Internet to shop online (Bisdee, 2007; Yulihasri \& Daud, 2011). This is consistent with the work of Childers et al. (2001) which argued that online retailers which are able to provide online shopping sites which are clear and understandable, with less mental effort requirement, and allow consumers to shop the way they want to shop results in ease of use perceptions in consumer minds with favourable attitudinal attachment to online retailers which are able to do so. Accordingly, the study proposes that:

H1: Consumers' perceived ease of use of online shopping sites will positively influence attitude towards online shopping.

\subsection{Perceived Usefulness (PU)}

PU is another major determinant of attitude toward use in the TAM model (Davis, et al., 1989). PU is defined as the degree to which the user believes that the technology will enhance the performance of an activity (Davis, 1989). According to McCloskey (2004), the ability to improve shopping performance, shopping productivity, and most importantly, accomplishing shopping goals, were concluded as valid determinants as to what makes consumers' shopping activity a success. This is in line with the findings of Barkhi et al. (2008) as their study suggests that consumers will develop favourable attitudes toward products and/or services that they believe to provide sufficient benefits or attributes toward a solution and negative attitudes toward those that are inadequate. Given this scenario, Kim et al. (2003) argued that online shopping sites which provide functions which aid consumers in making better shopping decisions will be perceived as useful. The same logic was observed in the work of Bisdee (2007) as online shopping sites which are able to provide useful services to consumers and services which are not available through traditional shopping (e.g. comparison between products at a glance) will be perceived as useful by consumers, and thus leads to the development of favourable attitudes toward online shopping. This notion is supported by Childers et al. (2001) whereby their findings suggest that consumers which had favourable attitudes toward online shopping were found to perceive online retailers as being useful as online retailers were able to enhance their shopping productivity, effectiveness and ability. Hence, it is expected that:

H2: Consumers' perceived usefulness of online shopping sites will positively influence attitude towards online shopping.

\subsection{Relationship between PEOU and PU}

Perceived ease of use has been empirically verified by many studies as a predictor of perceived usefulness (King $\& \mathrm{He}, 2006)$. When all other factors are equal, users are likely to consider a technology useful when they perceive it as easy to use (Bruner \& Kumar, 2005). Nonetheless, the relationship remains contradictory (Aladwani, 2002). The work of Gefen and Straub (1997) concluded that the relationship was not significant in predicting e-mail acceptance as a technology, while more recent researches (e.g. Jantan, et al., 2001; Shyu \& Huang, 2011) proved otherwise. However, in existing studies around the area of electronic commerce, both are surmised to be closely linked as Ramayah and Ignatius (2005) argued that consumers who perceive that online shopping is effortless should in turn develop a tendency to perceive it as useful. The rationale behind such a phenomenon is due to the fact that consumers would inherently try to mould his or her perception of online shopping based on his or her own experiences in engaging in online shopping and the ease in which the shopping activity was executed. This is in line with the work of Heijden (2000) which suggests that the easier it is for consumers to use online shopping sites, the more useful online shopping will be perceived by consumers. Therefore, this study anticipates that:

H3: Consumers' perceived ease of use of online shopping sites will have a positive influence on their perceived usefulness towards online shopping. 


\subsection{Relationship between Attitude and Intention}

Attitude has long been identified as a cause of intention (Suki \& Ramayah, 2010). Fishbein and Ajzen (1975) have categorized attitude into two distinctive constructs: the first refers to attitude toward the object while the second refers to attitude toward the behaviour. While the former is referred to as a person's evaluation of a specified object, the latter points to a person's evaluation of a specified behaviour. Against this backdrop, the latter categorization of attitude is adapted as the conceptualized operationalization of attitude used in the TAM model - in which in the adapted form refers to the mediating affective response between usefulness and ease of use beliefs and intentions to use a target system (Suki \& Ramayah, 2010). In the context of online shopping, the website for an online retailer is the main contact point by which the online retailer and consumers interface in the online shopping process (Ahn, et al., 2004). Past scholars have emphasised the understanding of user expectations and how they feel about the websites that they use (Chen, et al., 2002; Suh \& Han, 2002). In the work of Al-Rafee and Cronan (2006), attitude was found to be the most significant construct in influencing behavioural intention. Notably, the more positive a consumers' attitude towards online shopping, the higher the intention he or she has to engage in online shopping (Ahn, et al., 2004). Thus, the study posits that:

H4: Consumers' attitude towards online shopping will positively influence intention to engage in online shopping.

\section{Research Methodology and Design}

The current study employed a survey research in order to understand how consumers form their attitudes and make online shopping intentions.

In terms of data collection, self-administered questionnaires that consists of 7 socio-demographic questions and 28 questions using a 5-point Likert scale measuring the research constructs were administered to 350 consumers (regardless of age but with some screening criteria) in shopping malls within Klang Valley, Malaysia. The location Klang Valley was a strategic choice as it is the only place in Malaysia that consists of residents who come from all the 14 different states in Malaysia and thus enhances the generalization of results to all Malaysians. The age range was intentionally left unbounded to discover the actual distribution of consumers who are exposed to online shopping based on a random sample. A list of shopping malls around the area was generated and a simple random sample method was used to select shopping malls as sites of this study. A letter of permission was submitted to the selected shopping malls and all granted permission to carry out the process of administering of questionnaires at the respective shopping malls. While it may be argued that online shopping sites would be a much better site for the study, the fact that no Malaysian shopping websites allow for the administration of external questionnaires along with the high ambiguity results often projected in online questionnaires would hinder efforts to obtain results which are less-biased and less-error prone. Participation was voluntary and no incentives were offered to any respondent's participation. Upon selection of locations, systematic sampling was employed for the distribution of questionnaire to respondents. The researchers visited the shopping malls for a specific period and selects every $k$ th person that passes by and asks whether they have attempt to shop online previously (this is merely a sample criteria and does not amount to purposive sampling) to ensure a randomized sample is obtained. If a respondent nods to agreement, the researchers subsequently ask for permission to take some of the respondent's time to answer the questionnaire. The researchers were open to questions and were ready to answer any questions posed regarding any uncertainties of the respondent when answering the questionnaire. For those who answered no, the researchers terminated the conversation politely and did not administer the questionnaire to them.

In terms of data analysis, a descriptive analysis was initially performed to provide information pertaining to the demographics of the respondents. Next, factor analysis and reliability testing was carried out to test the validity and reliability of the questions used (questions are obtained from an extensive literature search) to measure the research constructs. After that, an associative analysis in the form of a correlation analysis was conducted to test for existence of multi-colinearity. Then, multiple regression analyses were performed to test the relationship between the whole set of predictors and the dependent variables under the current study. Subsequently, unstandardized residuals from the regression analyses were saved and tested for normality using the One-Sample Kolmogorov Smirnov Test. Later, hypothesis testing was subsequently conducted to determine whether hypothesis proposed based upon a review from existing literature are support or not supported. Lastly, implications of the results from the analysis are discussed and recommendations are provided. 


\section{Data Analysis and Findings}

\subsection{Respondent Demographics}

Table 2 presents a summary of respondent socio-demographics profile. In terms of gender, more females were found to have made an attempt to shop online as compared to males. Although this finding contradict the findings of past electronic commerce researches in developed countries such as those of Korgaonkar and Wolin (1999) and Swinyard and Smith (2003), whereby it was concluded that online shoppers tend to be males, it is suggested that there is a variation between gender of online shoppers in developed and developing countries as the current finding conformed to the recent finding of Delafrooz et al. (2010) and Hashim et al. (2009) which concluded in a similar percentage, whereby it indicated that most online shoppers in developing countries, such as Malaysia, were females. A similar state of affair can also be observed in relation to age. Typically, this study does not conform to the notion concluded in several studies in the developed countries context, such as those of Bhatnagar et al. (2000) which suggests that online shoppers tend to be older consumers. In fact, it was found that the majority of online shoppers in Malaysia fall in a combined category of age 30 and below, which suggests that online shoppers are actually younger in age. This is supported by studies carried out in developing countries such as those of Suki (2001) and Sulaiman et al. (2008) whereby it was also concluded that most online shoppers are considered young as most of them are below the age of 30 . In terms of marital status, most respondents were single $(63.4 \%)$ whereas $33.4 \%$ were married while only $3.1 \%$ of them were divorced. According to Peng (2007), the average age of marriage in Malaysia has been on an increasing trend over the years and was last reported to be 28.8 years in 2007, which may explain the high number of respondents being single in this research. The income levels were not similar across the respondents, but no clear pattern could be found. As such, this research can only report that most respondents earned between a combined income range of RM2001 to RM4000 - 53.4\%. Majority of the respondents (70.9\%) are working full time while $16.9 \%$ and $8 \%$ are students and working part-time respectively. Relationally, this finding may be attributed to the earlier findings whereby a large proportion of the respondents are in the working age category of 21 to 50 years. Nevertheless, those below 20 and some who are in their $20 \mathrm{~s}$ are still studying and may be working part time and hence, contributed to the numbers observed in student and part time occupations. In terms of highest academic qualification, most respondents have an undergraduate qualification (49.7\%), while $43.7 \%$ have last studied until high school and only $6.6 \%$ hold a postgraduate qualification. In other words, a large majority of respondents had a graduate background. Finally, in terms of race, the Chinese group was the highest contributor of the total respondents (48.6\%) while the second highest and third highest groups were represented by Malays (45.7\%) and Indians (5.7\%) respectively. Relationally, these descriptions are somewhat similar with the current population of the Malaysian internet users (Alam, et al., 2008).

\subsection{Factor Analysis and Reliability Testing}

Factor analysis and reliability testing were performed to ensure that all research constructs are reliable. Firstly, factor analysis was executed in order to reduce the complexity of research constructs, as well as ensuring that minimal latent constructs were employed to explain the shared variance of measured constructs use in the questionnaire (Henson \& Roberts, 2006). Secondly, Cronbach's alpha was utilized to ensure consistency of the survey data (Wang, et al., 2005). Cronbach's alpha is based on average correlation of items within the test because it will be interpreted as coefficient (Coakes, et al., 2010). A common rule of thumb is that indicators should have a Cronbach's alpha of at least 0.7 to judge the set of items as reliable (Peterson, 1994). The results for these two tests are compiled in Table 2.

Factors loading ranged from 0.779 to 0.975 , Cronbach's alpha was calculated for each factor, and each was found reliable ( $a=0.960,0.959,0.944$, and 0.954 respectively). These four factors were: perceived ease of use, perceived usefulness, attitude toward online shopping, and intention to shop online.

\subsection{Correlation Analysis}

Correlation analysis was performed to examine the relationship between perceived ease of use, perceived usefulness, attitude toward online shopping, and intention to shop online. The results support the non-existence of multi-colinearity as all correlation values are below 0.7 .

\subsection{Regression Analysis}

Regression analysis is conducted to test the relationship between the whole set of predictors and dependent variable. Outliers were removed and Figure 2 represents the direction and strength of each independent variable to the dependable variable and it shows that perceived ease of use, perceived usefulness and attitude towards online shopping are all positively related at $\mathrm{p}<0.01$. 
The general forms of the basic regression test are denoted below as equation one, three and five whilst the expanded models are written as equation two, four and six.

Where:

$$
Y=\alpha_{1}+\alpha_{2} X_{1}+\alpha_{3} X_{2}+\epsilon
$$

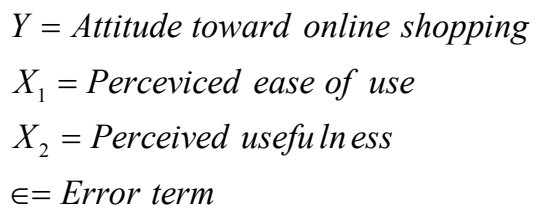

Where:

$$
\begin{aligned}
& \hat{Y}=0.736+0.395 X_{1}+0.410 X_{2} \\
& Y=\alpha_{1}+\alpha_{2} X_{1}+\epsilon
\end{aligned}
$$

$$
\begin{aligned}
& Y=\text { Perceived usefuln ess } \\
& X_{1}=\text { Perceviced ease of use } \\
& \in=\text { Error term }
\end{aligned}
$$

Where:

$$
\begin{aligned}
& \hat{Y}=0.254+0.960 X_{1} \\
& Y=\alpha_{1}+\alpha_{2} X_{1}+\epsilon
\end{aligned}
$$

$$
\begin{aligned}
& Y=\text { Intention to shop online } \\
& X_{1}=\text { Attitude toward online shopping } \\
& \epsilon=\text { Error term } \\
& 4.5 \text { One-Sample Kolmogorov Smirnov Test } \\
& \hat{Y}=-0.182+1.027 X_{1}
\end{aligned}
$$

A normality test was carried out based on the regression analyses. The One-Sample Kolmogorov Smirnov Test for normal distribution showed $p=0.850, p=0.053$ and $p=0.054$, all which are greater than $p>0.05$, and hence, a normal distribution can be assumed.

\subsection{Hypothesis Testing}

Hypothesis testing is performed to determine whether hypotheses proposed based upon a review from existing literature are supported or not supported. Table 5 projects the results from the testing of hypotheses. All four proposed hypotheses (i.e. H1-H4) that emerged from the literature review are supported based on the results from the regression analysis.

\section{Implications and Recommendations}

The first hypothesis posited that consumer PEOU will have a positive effect on attitude towards online shopping. Results revealed significant result $(\beta=0.395 ; p=0.000)$. Thus, $\mathrm{H} 1$ is supported. This suggests that the ease of use of technological interfaces and tools on online shopping sites are imperative in predicting the online shopper's attitude towards online shopping. Specifically, this study further contends that consumers would only develop favourable attitudes toward online shopping if online shopping sites are easy to use. This result is analogous to Bisdee (2007), Buton-Jones and Hubona (2005), Childers et al. (2001), Davis (1989), Davis et al. (1989), Selamat et al. (2009), Teo (2001), and Yulihasri and Daud (2011) stating that PEOU is a major determinant of attitude towards behaviour. Given this orientation, online retailers are recommended to make their digital marketplace simple to learn and easy for consumers to become skilful at using the technological interfaces and tools on the site i.e. as user friendly as possible. Webpage layout and structure should be designed in a way that makes potential customers easy to find what they want. Features that facilitate the comparability between product and service offerings and site maps will aid to this cause. Additionally, online retailers can provide interactive features, such as live customer support and chat rooms for shoppers, that facilitates flexible multiple interactions between consumers and between consumers and online retailer. Furthermore, to support online shopping adoption, system developers for online shopping sites could focus on developing effective user guidance, such as video tutorials and step-by-step visual e-how guides, to aid consumers who are new or unfamiliar with online shopping. Most importantly, as the ease of browsing at online shopping sites had the highest factor loading among the measurement items for perceived ease of use, online retailers are strongly encourage to ensure that online shopping sites are easy to browse. Features and designs which causes browsing 
difficulties, such as pop-up banners, small fonts and eye glaring colours, should avoided.

Further investigation of study was performed on the second proposed hypothesis on whether there is significant relationship between PU and attitude towards online shopping. Findings in Figure 2 confirmed that PU $(\beta=$ $0.410 ; p=0.000$ ) is significantly related to attitude towards online shopping. Hence, $\mathrm{H} 2$ is verified. The positive attitude towards online shopping is due to reasons that consumers perceive that online shopping improves their shopping performance and productivity. To consumers, the degree to which the online shopping site is perceived to be useful strongly influences their attitude. If online shopping sites are perceived to be useful, then consumers form positive attitudes and strong intentions to shop online. They would find that online shopping is very useful as it would enhance their shopping effectiveness. This corroborates the findings by Barkhi et al. (2008), Bisdee (2007), Childers et al. (2001), Davis (1989), Davis et al. (1989), Kim et al. (2003), and McCloskey (2004). Given the scenario, this study suggests a few recommendations for online retailers. It is suggested that online shopping sites provide facilities that help consumers to keep track on their shopping goals. In this respect, a digital shopping list could be provided on a sidebar. Additionally, online retailers should take note about the importance of shopping performance to consumers. In this situation, it is worthwhile to consider providing information and services that helps consumers save e.g. time and/or money. Since the operational cost of digital retail stores is much lower as compared to those in the brick-and-mortar environment, less expensive final price tags should be considered. Delivery services are encouraged as it would provide much convenience to consumers as they do not need to travel to source and purchase particular products and/or services. Also, features which enhance shopping productivity could also be employed. Search engines for online shopping sites are recommended as it helps consumers to make timelier purchase decisions and aids towards search for product information within a shorter time frame.

Next, the third hypothesis exhibited a significant relationship between PEOU and PU $(\beta=0.960 ; \mathrm{p}=0.000)$. Its $p$-value is $<0.05$, posited that $\mathrm{H} 3$ is supported by the data. This suggests that the ease of use of technological interfaces and tools on online shopping sites have a significant influence on consumers' perceived usefulness of online shopping. To consumers, the degree to which the online shopping site is perceived to be easy to use strongly influences their perceived usefulness of online shopping. If online shopping sites are perceived to be effortless, then consumers form perceptions of online shopping as useful. The results suggest that consumers inherently mould their perception of online shopping based on their own experiences in shopping online and the ease in which their shopping activity was executed. This result validates the postulation in the work of Bruner and Kumar (2005), Heijden (2000), Jantan et al. (2001), King and He (2006), Ramayah and Ignatius (2005), and Shyu and Huang (2011) that suggests PEOU is a lynchpin for PU. As such, online retailers are recommend to prioritize endeavours focusing on establishing and enhancing the ease of use of online shopping sites as the easier it is for consumers to use online shopping sites, the more useful online shopping will be perceived by consumers, thereby creating a positive dual-effect towards the formation of favourable consumer attitudes toward online shopping.

Lastly, the fourth hypothesis proposed that attitude towards online shopping will have a positive effect on intention to shop online. Attitude towards online shopping exhibited a significant relationship with intention to shop online $(\beta=1.027 ; p=0.000)$. Its $p$-value is $<0.05$, posited that $\mathrm{H} 4$ is strongly supported. Using online shopping sites as a channel to shop for products and/or services is a good idea. Thus, the significant role of attitudes in shaping behavioural intention has been visible when a relationship between attitude and behavioural intention is studied. The assumption that attitude towards online shopping have a strong, positive direct influence on intention to shop online is reinforced when the coefficients of attitude is examined (refer Figure 2).

\section{Limitations and Future Research Directions}

Despite the exploratory nature of this study, it managed to elucidate on the status quo of online shopping in Malaysia through sufficient empirical research. Nonetheless, the results of this study are based upon a general overview on the overall encounter to shop via the Internet. The perception constructs of PEOU and PU can be further examined in light of the type of products and services that are intended to be purchased by consumers through the online shopping channel. Future research is recommended to explore technology acceptance of online shopping in a scenario base setting e.g. shopping products and services that are segregated into their functions which in turn allows for a formation of an index to be accorded to each of those functions based on the importance of both the perception constructs. Hence, more categorical-focused recommendations can be made based on the quantity of effect that is involved in each perception construct.

While the findings of the significant relationships between the TAM constructs may be applicable in the online shopping setting, the TAM needs to be extended to include other belief constructs. Future research is encouraged 
to further extend the TAM to encompass other theoretical constructs. According to Luo (2002), a major trait of the Internet is its provision for interactive features. In turn, a natural progression of this study is to look at the influence of web atmospherics in influencing the formation of consumer attitudes toward online shopping and their subsequent intention to shop online. Nonetheless, some system developers have got themselves in an overly immerse situation with the use of virtualization technologies and such excessive application of digital features have often lead to web irritation. In line with this, it would be potentially fruitful for future researches to explore the role of consumer gratification and web irritation on the acceptance of online shopping.

The influence of demographics was not investigated in this research. Notably, this research only presented the demographic characteristics of Malaysians. Nevertheless, several differing findings as compared to majority of other electronic commerce research findings were encountered. An example seen in the current study is that the female gender was found to be the larger majority of Malaysians who have a previous encounter to shop online as compared to the findings of Korgaonkar and Wolin (1999) and Swinyard and Smith (2003) which suggests the opposite gender. Hence, the potential outcome of such investigation is likely to be fruitful and highly sought-after as the moderating effects of demographic variables, such as age, gender and race, may provide contrasting responses and further contribute to deeper understanding of consumers' attitudinal formation and intention to do shopping online.

\section{Conclusion}

This paper has examined relationship between PEOU, PU, attitude towards online shopping, and consumers' intention to shop online. Results showed that consumers' intention to shop online is determined by their attitude towards online shopping. Further, the results highlighted the importance of PEOU and PU of online shopping sites towards consumers' attitude towards online shopping in terms of how easy or effortless and how useful online shopping sites are in creating a favourable shopping environment. All things considered, the current findings significantly enhance understanding of user acceptance of online shopping. Consideration of the factors identified should lead to more successful adoption of online shopping. Results suggest consumers' of online shopping need to be provided with effortless and useful web interfaces and online shopping technologies. Future research can further evaluate and analyse the technology acceptance of consumers toward online shopping from a larger perspective by creating a technology acceptance index for different product and service categories, extending the TAM to include other belief constructs, and the moderating effects of demographic variables on the technology acceptance relationships.

\section{References}

Ahn, T., Ryu, S., \& Han, I. (2004). The impact of the online and offline features on the user acceptance of Internet shopping malls. Electronic Commerce Research and Applications, 3(4), 405-420. http://dx.doi.org/10.1016/j.elerap.2004.05.001

Ajzen, I. (1991). The theory of planned behaviour. Organizational Behaviour and Human Decision Process, 50(2), 179-211. http://dx.doi.org/10.1016/0749-5978(91)90020-T

Aladwani, A. M. (2002). The development of two tools for measuring the easiness and usefulness of transactional web sites. European Journal of Information Systems, 11(3), 223-234. http://dx.doi.org/10.1057/palgrave.ejis.3000432

Alam, S. S., Bakar, Z., Ismail, H., \& Ahsan, M. N. (2008). Young consumers online shopping: an empirical study. Journal of Internet Business, 1(5), 81-98.

Al-Rafee, S., \& Cronan, T. P. (2006). Digital piracy: factors that influence attitude toward behaviour. Journal of Business Ethics, 63(3), 237-259. http://dx.doi.org/10.1007/s10551-005-1902-9

Barkhi, R., Belanger, F., \& Hicks, J. (2008). A model of determinants of purchasing from virtual stores. Journal of Organizational Computing and Electronic Commerce, 18(3), 177-196. http://dx.doi.org/10.1080/10919390802198840

Bhatnagar, A., Misra, S., \& Rao, H. R. (2000). On risk, convenience, and Internet shopping behaviour: why some consumers are online shoppers while others are not. Communications of the ACM, 43(11), 98-105. http://dx.doi.org/10.1145/353360.353371

Bisdee, D. (2007). Consumer Attitudes Review. Office of Fair Trading, June, 1-147.

Bobbit, L. M., \& Dabholkar, P. A. (2001). Integrating attitudinal theories to understand and predict use of technology-based self-service: the internet as an illustration. International Journal of Service and Industrial Management, 12(5), 423- 450. http://dx.doi.org/10.1108/EUM0000000006092 
Broekhuizen, T., \& Huizingh, E. K. R. E. (2009). Online purchase determinants: is their effect moderated by direct experience?. Management Research News, 32(5), 440-457. http://dx.doi.org/10.1108/01409170910952949

Bruner, G. C. II., \& Kumar, A. (2005). Explaining consumer acceptance of handheld Internet devices. Journal of Business Research, 58(5), 553-558. http://dx.doi.org/10.1016/j.jbusres.2003.08.002

Buton-Jones, A., \& Hubona, G. S. (2005). Individual differences and usage behaviour: revisiting a technology acceptance model assumption. The DATA BASE for Advances in Information Systems, 36(2), 58-77.

Chen, S. J., \& Chang, T. Z. (2003). A descriptive model of online shopping process: some empirical results. International Journal of Service Industry Management, 58(6), 556-569. http://dx.doi.org/10.1108/09564230310500228

Chen, L., Gillenson, M. L., \& Sherrell, D. L. (2002). Enticing online consumers: an extended technology acceptance perspective. Information and Management, 39(8), 705-719. http://dx.doi.org/10.1016/S0378-7206(01)00127-6

Chen, Q., \& Wells, W. D. (1999). Attitude toward the site. Journal of Advertising Research, 39(5), 27-37.

Childers, T. L., Carr, C. L., Peck, J., \& Carson, S. (2001). Hedonic and utilitarian motivations for online retail shopping behaviour. Journal of Retailing, 77(4), 511-535. http://dx.doi.org/10.1016/S0022-4359(01)00056-2

Chiu, C. M., Chang, C. C., Cheng, H. L., \& Fang, Y. H. (2009). Determinants of customer repurchase intention in online shopping. Online Information Review, 33(4), 761-784. http://dx.doi.org/10.1108/14684520910985710

Coakes, S. J., Steed, L., \& Ong, C. (2010). SPSS: analysis without anguish: version 17 for Windows, John Wiley and Sons, Australia.

Davis, F. D. (1989). Perceived usefulness, perceived ease of use, and user acceptance of information technology. MIS Quarterly, 13(3), 318-340. http://dx.doi.org/10.2307/249008

Davis, F. D., Bagozzi, R. P., \& Warshaw, P. R. (1992). Extrinsic and intrinsic motivation to use computers in the workplace. Journal of Applied Social Psychology, 22(14), 1111-1132. http://dx.doi.org/10.1111/j.1559-1816.1992.tb00945.x

Delafrooz, N., Paim, L. H., \& Khatibi, A. (2010). Understanding consumers internet purchase intention in Malaysia. African Journal of Business Management, 5(3), 2837-2846.

Fishbein, M., \& Ajzen, I. (1975). Belief, attitude, intention and behaviour: an introduction to theory and research, Addison-Wesley, California.

Forouhandeh, B., Nejatian, H., \& Ramanathan, K. (2011). The online shopping adoption: barriers and advantages in $2^{\text {nd }}$ ICBER 2011: Proceedings of the $2^{\text {nd }}$ International Conference on Business and Economic Research, ICBER, Kedah, Malaysia, 2149-2171.

Goldsmith, R. (2002). Explaining and predicting consumer intention to purchase over the Internet: an exploratory study. Journal of Marketing, 66(Spring), 22-28.

Gefen, D., Karahanna, E., \& Straub, D. W. (2003). Trust and TAM in online shopping: an integrated model. MIS Quarterly, 27(1), 51-90.

Gefan, D., \& Straub, D. W. (1997). Gender differences in the perception and use of e-mail: an extension to the technology acceptance model. MIS Quarterly, 21(4), 389-400. http://dx.doi.org/10.2307/249720

Grabner-Krauter, S., \& Kaluscha, E. A. (2003). Empirical research in on-line trust: a review and critical assessment. International Journal of Human-Computer Studies, 58(6), 783-812. http://dx.doi.org/10.1016/S1071-5819(03)00043-0

Haque, A., Sadeghzadah, J., \& Khatibi, A. (2006). Identifying potentiality online sales in Malaysia: a study on customer relationships online shopping. Journal of Applied Business Research, 22(4), 119.

Hashim, A., Ghani, E. K., \& Said, J. (2009). Does consumers demographic profile influence online shopping?: an examination using Fishbeins theory. Canadian Social Science, 5(6), 19-31.

Heijden, H. (2000). E-TAM: a revision of the technology acceptance model to explain websites revisits. Research Memorandum.

Henson, R. K., \& Roberts, J. K. (2006). Use of exploratory factor analysis in published research. Educational and Psychological Measurement, 66(3), 393-416. http://dx.doi.org/10.1177/0013164405282485 
Huang, E. (2008). Use and gratification in e-consumers. Internet Research, 18(4), 405-426. http://dx.doi.org/10.1108/10662240810897817

Jantan, M., Ramayah, T., \& Chin, W. W. (2001). Personal computer acceptance by small and medium companies evidence from Malaysia. Jurnal Manajemen and Bisnis, 3(1), 1-14.

Kamarulzaman, Y. (2008). Modelling consumer adoption of internet shopping. Communications of the IBIMA, 5(26), 217-227.

Kau, A. K., Yingchan, E. T., \& Ghose, S. (2003). Typology of online shoppers. Journal of Consumer Marketing, 20(2), 139-156. http://dx.doi.org/10.1108/07363760310464604

Keil, M., Beranek, P. M., \& Konsynski, B. R. (1995). Usefulness and ease of use: field study evidence regarding task considerations. Decision Support Systems, 13(1), 75-91. http://dx.doi.org/10.1016/0167-9236(94)E0032-M

Kim, J., \& Forsythe, S. (2010). Factors affecting adoption of product virtualization technology for online consumer electronics shopping. International Journal of Retailing and Distribution Management, 38(3), 190-204. http://dx.doi.org/10.1108/09590551011027122

Kim, S., Williams, R., \& Lee, Y. (2003). Attitude toward online shopping and retail website quality: a comparison of US and Korean consumers. Journal of International Consumer Marketing, 16(1), 189-203. http://dx.doi.org/10.1300/J046v16n01_06

King, W. R., \& He, J. (2006). A meta-analysis of the technology acceptance model. Information and Management, 43(6), 740-755. http://dx.doi.org/10.1016/j.im.2006.05.003

Korgaonkar, P. K., \& Wolin, L. D. (1999). A multivariate analysis of web usage. Journal of Advertising Research, 39(2), 53-68.

Krishna, R., \& Guru, S. (2010). Online shopping motivators and barriers. Media Asia, 37.

Legris, P., Ingham, J., \& Collerette, P. (2003). Why do people use information technology? A critical review of the technology acceptance model. Information and Management, 40(3), 191-204. http://dx.doi.org/10.1016/S0378-7206(01)00143-4

McCloskey, D. (2004). Evaluating electronic commerce acceptance with the technology acceptance model. Journal of Computer Information Systems, 44(22), 49- 57.

Mitchell, V. W., \& Greatorex, M. (1993). Risk perception and reduction in the purchase of consumer services. The Service Industries Journal, 13(4), 179-200. http://dx.doi.org/10.1080/02642069300000068

Nielson, A. C. (2008). World statistics on the number of internet shoppers. [Online] Available: http://www.multillingual-search.com/world-statistics-on-the-number-of-internet-shoppers/28/01/2008

Pastore, M. (2000). Young consumers shy away from e-commerce. [Online] Available: http://clickz.com/stats/big_picture/demographics/article.php/386591

Peng, T. N. (2007). Trends in delayed and non-marriage in Peninsular Malaysia. Asian Population Studies, 3(3), 243-261. http://dx.doi.org/10.1080/17441730701746391

Peterson, R. A. (1994). A meta-analysis of Cronbachs coefficient alpha. Journal of Consumer Research, 21(2), 381-391. http://dx.doi.org/10.1086/209405

Ramayah, T., \& Ignatius, J. (2005). Impact of perceived usefulness, perceived ease of use and perceived enjoyment on intention to shop online. ICFAI Journal of Systems Management, 3(3), 36-51.

Ramayah, T., Rouibah, K., Gopi, M., \& Rangel, G. J. (2009). A decomposed theory of reasoned action to explain intention to use Internet stock trading among Malaysian investors. Computers in Human Behaviour, 25(6), 1222-1230. http://dx.doi.org/10.1016/j.chb.2009.06.007

Roger, E. M. (1995). Diffusion of innovations. The Free Press, New York.

Salisbury, W. D., Pearson, R. A., Pearson, A. W., \& Miller, D. W. (2001). Perceived security and the World Wide Web purchase intention. Industrial Management and Data Systems, 101(4), 165-177. http://dx.doi.org/10.1108/02635570110390071

Selamat, Z., Jaffar, N., \& Ong, B. H. (2009). Technology acceptance in Malaysian banking industry. European Journal of Economics, Finance and Administrative Sciences, 1(17), 143-155. 
Schonfeld, E. (2010). Forrester Forecast: online retail sales will grow to $\$ 250$ billion by 2014. Techcrunch. [Online] Available: http://techcrunch.com/2010/03/08/forrester-forecast-online-retail-sales-will-grow-to-250-billion-by-2014

Shyu, S. H. P., \& Huang, J. H. (2011). Elucidating usage of e-government learning: a perspective of the extended technology acceptance model. Government Information Quarterly, 28(4), 491-502. http://dx.doi.org/10.1016/j.giq.2011.04.002

Suh, B., \& Han, I. (2002). Effect of trust on customer acceptance of Internet banking. Electronic Commerce and Applications, 1(3), 247-263. http://dx.doi.org/10.1016/S1567-4223(02)00017-0

Suki, N. B. M. (2001). Malaysian Internet users motivation and concerns for shopping online. Malaysian Journal of Library and Information Science, 6(2), 21-33.

Suki, N. M., \& Ramayah, T. (2010). User acceptance of the e-government services in Malaysia: structural equation modelling approach. Interdisciplinary Journal of Information, Knowledge and Management, 5(1), 395-413.

Sulaiman, A., Ng, J., \& Mohezar, S. (2008). E-ticketing as a new way of buying tickets: Malaysian perceptions. Journal of Social Science, 17(2), 149-157.

Swinyard, W. R., \& Smith, S. M. (2003). Why people (dont) shop online: a lifestyle study of the Internet consumer. Psychology and Marketing, 20(7), 567-597. http://dx.doi.org/10.1002/mar.10087

Teo, T. S. H. (2001). Demographic and motivation variables associated with Internet usage activities. Internet Research, 11(2), 125-137. http://dx.doi.org/10.1108/10662240110695089

Wang, F., Zhang, H., Zhang, H., \& Ouyang, M. (2005). Purchasing pirated software: an initial examination of Chinese consumers. The Journal of Consumer Marketing, 22(6), 2340-2351. http://dx.doi.org/10.1108/07363760510623939

Yuslihasri, I. A., \& Daud, A. K. (2011). Factors that influence customers buying intention on shopping online. International Journal of Marketing Studies, 3(1), 128-143.

Table 1. Summary of items and sources

\begin{tabular}{|c|c|c|c|}
\hline Variables & Constructs & $\begin{array}{l}\text { Number } \\
\text { of items }\end{array}$ & Sources \\
\hline $\begin{array}{l}\text { Socio-demographic } \\
\text { variables }\end{array}$ & $\begin{array}{l}\text { Gender, age, marital status, income, } \\
\text { occupation, highest academic } \\
\text { qualification, race. }\end{array}$ & 7 & $\begin{array}{l}\text { Ramayah et al. (2009); } \\
\text { Kim and Forsythe (2010). }\end{array}$ \\
\hline $\begin{array}{l}\text { Independent } \\
\text { variables/Dependent }\end{array}$ & Perceived usefulness & 7 & $\begin{array}{l}\text { Bruner and Kumar (2005); } \\
\text { Ramayah et al. (2009). }\end{array}$ \\
\hline \multirow[t]{2}{*}{ variables } & Perceived ease of use & 7 & $\begin{array}{l}\text { Chen and Wells (1999); } \\
\text { Buton-Jones and Hubona } \\
\text { (2005). }\end{array}$ \\
\hline & Attitude toward online shopping & 7 & $\begin{array}{l}\text { Ramayah et al. (2009); } \\
\text { Kim and Forsythe (2010). }\end{array}$ \\
\hline Dependent variable & Intention to shop online & 7 & $\begin{array}{l}\text { Broekhuizen and Huizingh } \\
\text { (2009); Chiu et al. (2009). }\end{array}$ \\
\hline
\end{tabular}


Table 2. Summary of respondent socio-demographics profile

\begin{tabular}{|c|c|c|c|}
\hline Socio-demographic variables & Description & Frequency & Percent \\
\hline \multirow[t]{2}{*}{ Gender } & Male & 107 & 30.6 \\
\hline & Female & 243 & 69.4 \\
\hline \multirow[t]{5}{*}{ Age } & Below 20 & 34 & 9.7 \\
\hline & 21 to 30 & 199 & 56.9 \\
\hline & 31 to 40 & 99 & 28.3 \\
\hline & 41 to 50 & 12 & 3.4 \\
\hline & 51 and above & 6 & 1.7 \\
\hline \multirow[t]{3}{*}{ Marital status } & Single & 222 & 63.4 \\
\hline & Married & 117 & 33.4 \\
\hline & Divorce & 11 & 3.1 \\
\hline \multirow[t]{6}{*}{ Income } & RM1000 and below & 58 & 16.6 \\
\hline & RM1001 to RM2000 & 21 & 6 \\
\hline & RM2001 to RM3000 & 112 & 32 \\
\hline & RM3001 to RM4000 & 75 & 21.4 \\
\hline & RM4001 to RM5000 & 39 & 11.1 \\
\hline & RM5000 and above & 45 & 12.9 \\
\hline \multirow[t]{4}{*}{ Occupation } & Student & 59 & 16.9 \\
\hline & Full time employee & 248 & 70.9 \\
\hline & Part time employee & 28 & 8 \\
\hline & Unemployed & 15 & 4.3 \\
\hline \multirow[t]{3}{*}{ Highest academic qualification } & High school & 153 & 43.7 \\
\hline & Undergraduate & 174 & 49.7 \\
\hline & Postgraduate & 23 & 6.6 \\
\hline \multirow[t]{3}{*}{ Race } & Malay & 160 & 45.7 \\
\hline & Chinese & 170 & 48.6 \\
\hline & Indian & 20 & 5.7 \\
\hline
\end{tabular}


Table 3. Summary of factor analysis and Cronbach's alpha test

\begin{tabular}{|c|c|c|c|}
\hline Dimension & Item & $\begin{array}{l}\text { Factor } \\
\text { Loading }\end{array}$ & $\begin{array}{c}\text { Cronbach's } \\
\text { Alpha }\end{array}$ \\
\hline Perceived ease & I find most online shopping sites easy to use. & 0.927 & 0.960 \\
\hline \multirow[t]{6}{*}{ of use } & I find it easy learning to use most online shopping sites. & 0.913 & \\
\hline & $\begin{array}{l}\text { I find it easy to use most online shopping sites to find what I } \\
\text { want. }\end{array}$ & 0.847 & \\
\hline & $\begin{array}{l}\text { I find it easy to become skilful at using most online shopping } \\
\text { sites. }\end{array}$ & 0.779 & \\
\hline & $\begin{array}{l}\text { I find it easier to compare products when shopping at online } \\
\text { retailers. }\end{array}$ & 0.915 & \\
\hline & I feel that most online shopping sites are flexible to interact with. & 0.872 & \\
\hline & I am able to browse online shopping sites with ease. & 0.932 & \\
\hline \multirow[t]{7}{*}{$\begin{array}{l}\text { Perceived } \\
\text { usefulness }\end{array}$} & $\begin{array}{l}\text { I am able to accomplish my shopping goals more quickly when I } \\
\text { shop online. }\end{array}$ & 0.861 & 0.959 \\
\hline & $\begin{array}{l}\text { I am able to improve my shopping performance when I shop } \\
\text { online (e.g. save time or money). }\end{array}$ & 0.918 & \\
\hline & $\begin{array}{l}\text { I am able to increase my shopping productivity when I shop } \\
\text { online (e.g. make purchase decisions or find product information } \\
\text { within the shortest time frame). }\end{array}$ & 0.938 & \\
\hline & $\begin{array}{l}\text { I am able to increase my shopping effectiveness when I shop } \\
\text { online (e.g. get the best deal or find the most information about a } \\
\text { product). }\end{array}$ & 0.934 & \\
\hline & $\begin{array}{l}\text { I find the website of online retailers useful in aiding my purchase } \\
\text { decisions. }\end{array}$ & 0.780 & \\
\hline & Shopping from online retailers improves my purchase decisions. & 0.785 & \\
\hline & $\begin{array}{l}\text { Shopping from online retailers makes it easier for me to satisfy } \\
\text { my needs. }\end{array}$ & 0.933 & \\
\hline \multirow{7}{*}{$\begin{array}{l}\text { Attitude toward } \\
\text { online shopping }\end{array}$} & I am comfortable to shop from online shopping sites. & 0.818 & 0.944 \\
\hline & I like to purchase what I need from online shopping sites. & 0.880 & \\
\hline & I like to seek for product information from online shopping sites. & 0.809 & \\
\hline & I feel happy when I do my shopping online. & 0.854 & \\
\hline & I feel shopping online is a good idea. & 0.793 & \\
\hline & I feel shopping online is a wise choice. & 0.869 & \\
\hline & I hold a positive evaluation of shopping online. & 0.870 & \\
\hline \multirow[t]{7}{*}{$\begin{array}{l}\text { Intention to } \\
\text { shop online }\end{array}$} & $\begin{array}{l}\text { It is likely that I will continue to purchase products from online } \\
\text { retailers in the future. }\end{array}$ & 0.846 & 0.954 \\
\hline & $\begin{array}{l}\text { I intend to continue purchase products from the Internet in the } \\
\text { future. }\end{array}$ & 0.887 & \\
\hline & I would likely visit an online shopping site to shop for my needs. & 0.975 & \\
\hline & I plan to do more of my shopping via online shopping sites. & 0.814 & \\
\hline & $\begin{array}{l}\text { When I need to buy a particular product, I would search for an } \\
\text { online retailer which has the product. }\end{array}$ & 0.927 & \\
\hline & $\begin{array}{l}\text { There is a substantial chance that I would purchase the same } \\
\text { product from an online retailer. }\end{array}$ & 0.886 & \\
\hline & $\begin{array}{l}\text { There is a substantial chance that I would purchase different } \\
\text { products from an online retailer. }\end{array}$ & 0.906 & \\
\hline
\end{tabular}


Table 4. Summary of correlation analysis

\begin{tabular}{lllll}
\hline & PEOU & PU & Attitude & Intention \\
\hline PEOU & 1 & & & \\
PU & $0.466^{* *}$ & 1 & & \\
Attitude & $0.614^{* *}$ & $0.470^{* *}$ & 1 & 1 \\
Intention & $0.582^{* *}$ & $0.504^{* *}$ & $0.562^{* *}$ & 1 \\
\hline
\end{tabular}

**. Correlation is significant at the 0.01 level (2-tailed).

Table 5. Summary of hypothesis testing

\begin{tabular}{lc}
\hline Hypotheses & Supported/Not Supported \\
\hline $\begin{array}{l}\text { H1: Consumers' perceived ease of use of online shopping sites will positively } \\
\text { influence attitude towards online shopping. }\end{array}$ & Supported \\
H2: Consumers' perceived usefulness of online shopping sites will positively & Supported \\
influence attitude towards online shopping. & \\
H3: Consumers' perceived ease of use of online shopping sites will have a positive & Supported \\
influence on their perceived usefulness towards online shopping. & \\
H4: Consumers' attitude towards online shopping will positively influence intention \\
to engage in online shopping.
\end{tabular}

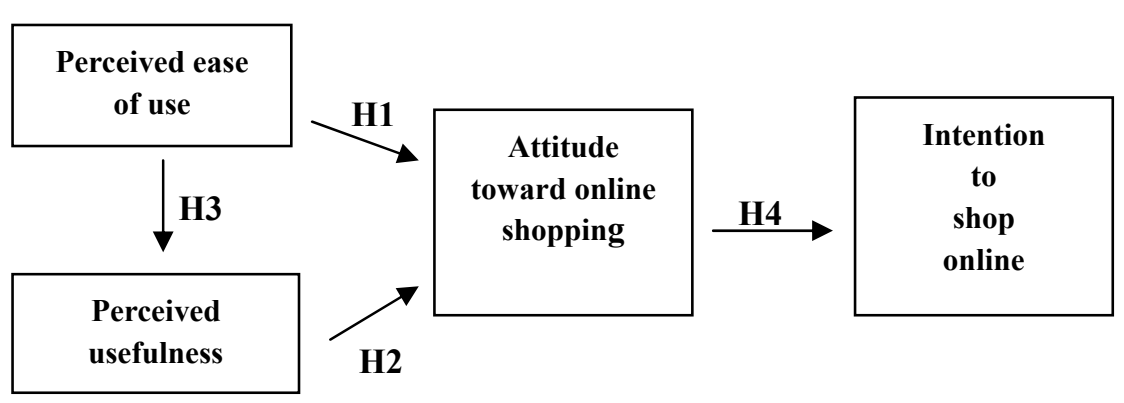

Figure 1. Research framework

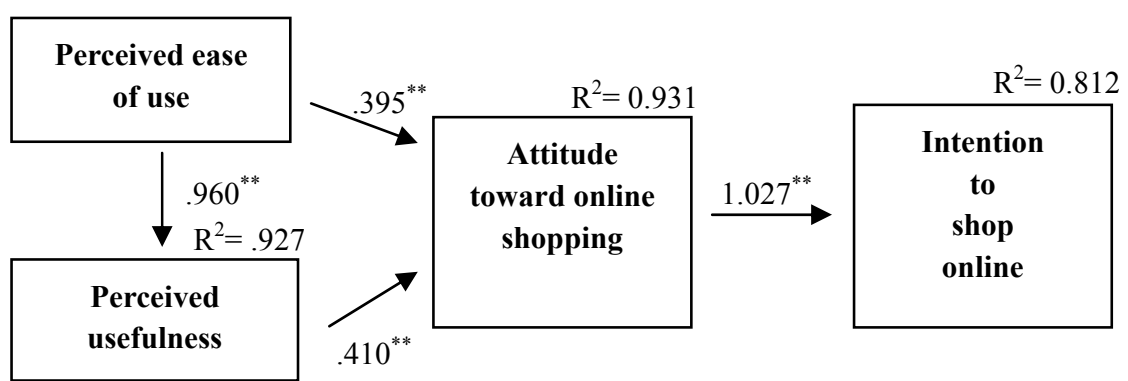

Figure 2. Research framework representing coefficients of each research construct 